\title{
RHEUMATOID ARTHRITIS IN A SUBTROPICAL POPULATION
}

\author{
BY \\ J. S. LAWRENCE, J. M. BREMNER, J. BALL, AND T. A. BURCH \\ From the Arthritis and Rheumatism Council Field Unit and Rheumatism Research Centre, Manchester University, and \\ the Institute of Arthritis and Metabolic Diseases, Bethesda, Maryland, U.S.A.
}

The prevalence of definite rheumatoid arthritis (R.A.) in seven Northern European populations studied by de Graff, Laine, and Lawrence (1963) was substantially the same. Comparisons with Pittsburgh in the United States also revealed little difference (Cobb and Lawrence, 1957). However, it has often been claimed that rheumatoid arthritis is rare in the tropics. If this were so it would prove a valuable clue to the aetiology of the disease. Proof, however, is lacking. Malawista, Boies, and Seides (1959) found no arthritis in a survey of 230 persons in Liberia, but their sample was selected, being chosen from employees attending a works clinic, who included few females in the older age groups, in whom the highest prevalence of arthritis occurs. Méndez-Bryan, Gónzalez-Alcover, and Roger (1964), in a Puerto-Rican population aged 18 and over, reported a prevalence of only 0.9 per cent. of probable or definite rheumatoid arthritis, but only those suspected of having rheumatoid arthritis as a result of a questionnaire were subjected to clinical examination, and many may thus have been missed.

One of the present authors (T.A.B.) observed nine persons with a positive bentonite flocculation test (B.F.T.), two of whom had rheumatic complaints, among 147 persons examined in an onchocerciasis survey in Venezuela, and four cases of classical or definite R.A., two with a positive B.F.T. These cases were demonstrated to him by Venezuelan physicians when he expressed an interest in the disease. Goodall (1956), who made a retrospective analysis of ninety arthritics attending the Zomba African Hospital, Nyasaland, found only two cases and these were atypical. Gelfand (1957) stated that rheumatoid arthritis was rarely seen. Harries (1962) reported a single case from Nairobi and Hijmans, Valkenburg, Muller, and Gratama (1964) saw three cases of rheumatoid arthritis in Liberia. Hall (1965) found it to be the commonest single cause of inflammatory polyarthritis of more than 3 weeks' duration in Kenya, and reported eight cases among 31 polyarthritics. Thus it is clear that the disease does occur in the tropics but there is no information as to whether it is more or less frequent than in temperate climates. It was therefore decided to carry out a survey on a Jamaican population in the Lawrence Tavern district using the same clinical observers and serologists as in a population survey in Wensleydale in NorthWest England and to compare the results in the two rural populations.

\section{Method}

The Lawrence Tavern district of Jamaica is situated in the Blue Mountains, 17 miles north of Kingston, about $2,000 \mathrm{ft}$. above sea level. The hillsides are steep and the people live in small huts reached by footpaths leading from the rough roads. They grow bananas, breadfruit, coconuts, and sugar cane on small-holdings of 3 to 4 acres. In a few places the land is terraced for root crops, chiefly yams. The men are nearly all cultivators and the women make straw articles as well as working on the land and in the home. They often go barefooted and carry burdens on their heads. The population of 7,500 has been studied by the M.R.C. Epidemiological Unit under Dr. W. E. Miall for several years.

The population, as defined in the initial M.R.C. survey in 1959-60, contained in the three decades chosen for the 1962 survey 2,234 persons as follows:

\begin{tabular}{c|c|c}
\hline \multirow{2}{*}{\begin{tabular}{c|c} 
Decades of Age \\
(yrs)
\end{tabular}} & \multicolumn{2}{|c}{ Number in Sample } \\
\cline { 2 - 3 } & Males & Females \\
\hline $35-44$ & 439 & 402 \\
$45-54$ & 430 & 387 \\
$55-64$ & 290 & 286 \\
\hline Total & 1,159 & 1,075 \\
\hline
\end{tabular}


It was decided to take 100 males and 100 females at random from each of these age groups.

Respondents were brought to a clinic in Lawrence Tavern and were asked about rheumatic and other symptoms and were graded 0 to $4^{*}$ for R.A., gout, osteoarthrosis, disk degeneration, and other rheumatic conditions. A sample of blood was taken and $x$ rays of the hands, feet, cervical and lumbar spine, and knees. An $x$ ray of the pelvis was taken in all the males and in those females who were aged 45 and over. The $x$ rays were mixed with those taken in a survey of a population in Wensleydale and read blind. Serum was tested for rheumatoid factors by the sheep-cell agglutination test (S.C.A.T.) and the B.F.T. All these results were later summarized by the C.I.O.M.S. criteria for active and inactive R.A. (1963).

\section{Completion Rate}

Of the 300 males in the sample, 263 were examined, a completion rate of 88 per cent. (Table I). All had a clinical examination but eleven either refused a blood test or a sample was not obtained and two refused an $x$ ray. Of the 300 females, 273 were examined (a completion rate of 91 per cent., nineteen having no blood test and five no $x$ ray; for two females the clinical data were incomplete.

$* 0=$ None; 1 = Doubtful; $2=$ Mild; $3=$ Moderate; $4=$ Severe.
Prevalence of Rheumatoid Arthritis (C.I.O.M.S. Criteria)

Active Rheumatoid Arthritis, both "definite" and "probable", was present more often in the Jamaicaron sample than would have been expected from the Wensleydale sample (Table II).

In 27 of 48 cases the grading "probable" wa obtained from the presence of bilateral smal effusions in cool knees with no soft tissue swellings In four of these cases there was radiological evidence of peripheral erosive arthritis, and three of the foup gave a history of pain in the knees. In eight cases the effusions were accompanied by a history of morning stiffness, and five of these had pain in the knees. In fifteen cases only the effusions score points in the C.I.O.M.S. scale and six of these has pain in the knees. Only one was given a clinicait diagnosis of definite R.A., and two were graded "doubtful". The difference between Jamaica andr Wensleydale just fails to be significant at the 5 per cent. level. In females the increase was limite to the probable group, but again was not statistically significant.

Inactive Rheumatoid Arthritis was slightly more frequent in the Jamaican males, but not in the females. Of the seven persons in this category three also had a grading of "definite" active R.A.

TABLE I

COMPLETION RATE IN JAMAICAN POPULATION SURVEY, BY SEX

\begin{tabular}{|c|c|c|c|c|c|c|c|}
\hline \multirow[b]{2}{*}{ Sex } & \multirow[b]{2}{*}{$\begin{array}{c}\text { Total } \\
\text { in } \\
\text { Sample }\end{array}$} & \multirow[b]{2}{*}{$\begin{array}{l}\text { Refused } \\
\text { or Not } \\
\text { Available }\end{array}$} & \multirow[b]{2}{*}{$\begin{array}{c}\text { Total } \\
\text { Examined }\end{array}$} & \multirow[b]{2}{*}{$\begin{array}{c}\text { Completion } \\
\text { Rate } \\
\text { (per cent.) }\end{array}$} & \multicolumn{3}{|c|}{ Examination } \\
\hline & & & & & $\begin{array}{c}\text { Clinical, } \\
x \text { ray, } \\
\text { Serum }\end{array}$ & $\begin{array}{c}\text { Clinical } \\
\text { and } x \text { ray } \\
\text { Only }\end{array}$ & $\begin{array}{c}\text { Clinical } \\
\text { and Serum } \\
\text { Only }\end{array}$ \\
\hline $\begin{array}{l}\text { Male } \\
\text { Female }\end{array}$ & $\begin{array}{l}300 \\
300\end{array}$ & $\begin{array}{l}37 \\
27\end{array}$ & $\begin{array}{l}263 \\
273\end{array}$ & $\begin{array}{l}88 \\
91\end{array}$ & $\begin{array}{l}250 \\
249\end{array}$ & $\begin{array}{l}11 \\
19\end{array}$ & $\begin{array}{l}2 \\
5\end{array}$ \\
\hline
\end{tabular}

TABLE II

RHEUMATOID ARTHRITIS BY C.I.O.M.S. CRITERIA IN JAMAICAN POPULATION SURVEY, BY SEX AND AGE GROUP

\begin{tabular}{|c|c|c|c|c|c|c|c|c|c|c|c|}
\hline \multirow{3}{*}{$\begin{array}{l}\text { Rheumatoid } \\
\text { Arthritis }\end{array}$} & \multirow{3}{*}{$\frac{\text { Sex }}{\substack{\text { Age } \\
\text { Group } \\
\text { (yrs) }}}$} & \multicolumn{5}{|c|}{ Male } & \multicolumn{5}{|c|}{ Female $†$} \\
\hline & & \multirow{2}{*}{ Total } & \multicolumn{2}{|c|}{ Probable } & \multicolumn{2}{|c|}{ Definite } & \multirow{2}{*}{ Total } & \multicolumn{2}{|c|}{ Probable } & \multicolumn{2}{|c|}{ Definite } \\
\hline & & & Actual & $\overline{\text { Expected }}{ }^{*}$ & Actual & Expected $*$ & & Actual & Expected* & Actual & Expected? \\
\hline \multirow[t]{2}{*}{ Active } & $\begin{array}{l}35-44 \\
45-54 \\
55-64\end{array}$ & $\begin{array}{l}91 \\
84 \\
88\end{array}$ & $\begin{array}{l}5 \\
4 \\
7\end{array}$ & $\begin{array}{l}2 \cdot 18 \\
2 \cdot 9 \\
1 \cdot 65\end{array}$ & $\begin{array}{l}0 \\
0 \\
4\end{array}$ & $\begin{array}{l}0 \\
1 \cdot 01 \\
0\end{array}$ & $\begin{array}{l}92 \\
83 \\
92\end{array}$ & $\begin{array}{r}6 \\
13 \\
13\end{array}$ & $\begin{array}{l}2 \cdot 9 \\
7 \cdot 5 \\
5 \cdot 4\end{array}$ & $\begin{array}{l}1 \\
2 \\
3\end{array}$ & $\begin{array}{l}1.01 \\
1.08 \\
4.03\end{array}$ \\
\hline & Total & 263 & 16 & $6 \cdot 7$ & 4 & $1 \cdot 0$ & 267 & 32 & $15 \cdot 8$ & 6 & $6 \cdot 1$ \\
\hline \multirow[t]{2}{*}{ Inactive } & $\begin{array}{l}35-44 \\
45-54 \\
55-64\end{array}$ & $\begin{array}{l}91 \\
84 \\
88\end{array}$ & $\begin{array}{l}0 \\
1 \\
4\end{array}$ & $\begin{array}{l}0 \\
0 \\
1 \cdot 63\end{array}$ & $\begin{array}{l}0 \\
0 \\
1\end{array}$ & $\begin{array}{l}0 \\
0.97 \\
0\end{array}$ & $\begin{array}{l}92 \\
83 \\
92\end{array}$ & 1 & $\begin{array}{l}0 \\
0 \\
1 \cdot 38\end{array}$ & & $\begin{array}{l}0 \\
1.06 \\
2.8\end{array}$ \\
\hline & Total & 263 & 5 & $1 \cdot 6$ & 1 & $1 \cdot 0$ & 267 & 1 & $1 \cdot 4$ & 0 & $3 \cdot 9$ \\
\hline
\end{tabular}

* Calculated from Wensleydale survey.

$\dagger$ In six females the data were inadequate to assess active R.A. 
other four scored only one or two points in the active category.

Thus there were no significant differences between Jamaica and Wensleydale for either active or inactive rheumatoid arthritis.

Clinical Rheumatoid Arthritis (Grade 2-4) was diagnosed at the time of the interview in fourteen of the Jamaican males-mild in eleven and moderate in three (Table III). Only the mild cases were more frequent in the Jamaican population and the difference was not significant except in the 55 to 64-year age group, which showed a much higher prevalence than the rest. The Jamaican females also had rather more mild disease but the difference was not significant. Neither males nor females in the Jamaican sample had severe disease, but only three severe cases would have been expected in a population of the same age and sex distribution in the United Kingdom and a larger sample would be required to be certain that severe disease is less common in Jamaica.

Radiological Evidence of Erosive Arthritis.-As radiographs provide a permanent record by which surveys carried out at widely different times and places may be compared, the radiological evidence constitutes the most important source of information on differences between populations.

Erosive arthritis (Grade 2 to 4 ) was present in the hands in eleven Jamaican males; this is roughly twice the expected amount, but it was mild in all cases (Table IV). The absence of moderate or severe disease is not statistically significant since only three moderate or severe cases would be expected in this sample. The Jamaican females similarly had twice the expected amount, all minimal. Taking males and females together, there was significantly more mild erosive arthritis of the hands in Jamaica than in Wensleydale, but significantly more moderate or severe cases in Wensleydale than in Jamaica.

Some degree of erosive arthritis in the feet was present in 32 Jamaican males and 21 females, a very significant increase over Wensleydale $(\mathrm{P}<0.01)$. Grade 3 to 4 changes were also more frequent in the Jamaican males but not significantly so. No Grade 3 to 4 changes were seen in Jamaican females. 23 of the 28 males with Grade 2 erosions had them in the 5th metatarsal head only, all but one being on the outer aspect, and only three being bilateral. The hands were affected in four of these 28 males, two of whom had clinical arthritis. Three others

TABLE III

PREVALENCE OF CLINICAL RHEUMATOID ARTHRITIS IN JAMAICA, BY AGE AND SEX

\begin{tabular}{|c|c|c|c|c|c|c|c|c|c|c|c|c|c|}
\hline \multirow{3}{*}{ Sex } & \multirow{3}{*}{$\begin{array}{l}\text { Age } \\
\text { Group } \\
\text { (yrs) }\end{array}$} & \multirow{3}{*}{$\begin{array}{c}\text { Total } \\
\text { No. } \\
\text { of } \\
\text { Cases }\end{array}$} & \multirow{3}{*}{0} & \multirow{3}{*}{1} & \multirow{3}{*}{2} & \multirow{3}{*}{3} & \multirow{3}{*}{4} & \multicolumn{6}{|c|}{ Grades of Clinical R.A. } \\
\hline & & & & & & & & \multicolumn{2}{|c|}{$2-4$} & \multicolumn{2}{|r|}{$3-4$} & \multicolumn{2}{|r|}{4} \\
\hline & & & & & & & & Actual & Expected $*$ & Actual & Expected* & Actual & Expected* \\
\hline \multirow[t]{2}{*}{ Male } & $\begin{array}{l}35-44 \\
45-54 \\
55-64\end{array}$ & $\begin{array}{l}91 \\
84 \\
88\end{array}$ & $\begin{array}{l}84 \\
76 \\
69\end{array}$ & $\begin{array}{l}6 \\
6 \\
8\end{array}$ & $\begin{array}{l}1 \\
2 \\
8\end{array}$ & 3 & & & & & & & \\
\hline & Total & 263 & 229 & 20 & 11 & 3 & & 14 & $8 \cdot 1$ & 3 & $2 \cdot 9$ & 0 & $0 \cdot 6$ \\
\hline \multirow[t]{2}{*}{ Female } & $\begin{array}{l}35-44 \\
45-54 \\
55-64\end{array}$ & $\begin{array}{l}93 \\
86 \\
92\end{array}$ & $\begin{array}{l}80 \\
72 \\
74\end{array}$ & $\begin{array}{l}7 \\
6 \\
6\end{array}$ & $\begin{array}{r}5 \\
8 \\
10\end{array}$ & $\begin{array}{l}1 \\
2\end{array}$ & & & & & & & \\
\hline & Total & $271 \dagger$ & 226 & 19 & 23 & 3 & & 26 & $19 \cdot 1$ & 3 & $4 \cdot 8$ & 0 & $2 \cdot 0$ \\
\hline
\end{tabular}

* Wensleydale.

t Two females had incomplete clinical data.

TABLE IV

GRADES OF EROSIVE ARTHRITIS IN THE JAMAICAN POPULATION SURVEY, BY SEX AND SITE

\begin{tabular}{|c|c|c|c|c|c|c|c|c|c|c|c|c|c|c|}
\hline \multirow{3}{*}{ Erosions } & \multicolumn{5}{|c|}{ Male } & \multicolumn{5}{|c|}{ Female } & \multicolumn{4}{|c|}{ Male + Female } \\
\hline & \multirow{2}{*}{ Total } & \multicolumn{2}{|c|}{$2-4$} & \multicolumn{2}{|c|}{$3-4$} & \multirow{2}{*}{ Total } & \multicolumn{2}{|c|}{$2-4$} & \multicolumn{2}{|c|}{$3-4$} & \multicolumn{2}{|c|}{$2-4$} & \multicolumn{2}{|c|}{$3-4$} \\
\hline & & Actual & Expected & Actual & Expected & & Actual & Expected & Actual & Expected & Actual & Expected & Actual & Expected \\
\hline $\begin{array}{l}\text { Hands } \\
\text { Feet }\end{array}$ & $\begin{array}{l}260 \\
260\end{array}$ & $\begin{array}{l}11 \\
32 \dagger\end{array}$ & $\begin{array}{l}5 \cdot 1 \\
6 \cdot 3\end{array}$ & $\begin{array}{l}0 \\
4\end{array}$ & $\begin{array}{l}2 \cdot 6 \\
2 \cdot 6\end{array}$ & $\begin{array}{l}268 \\
268\end{array}$ & $\begin{array}{l}15 \\
21 \dagger\end{array}$ & $\begin{array}{l}7 \cdot 5 \\
5 \cdot 0\end{array}$ & $\begin{array}{l}0 \\
0\end{array}$ & $\begin{array}{l}3 \cdot 7 \\
5 \cdot 0\end{array}$ & $\begin{array}{l}26 * \\
53 t\end{array}$ & $\begin{array}{l}12 \cdot 6 \\
11 \cdot 3\end{array}$ & $\begin{array}{c}0 * \\
4\end{array}$ & $\begin{array}{l}6 \cdot 3 \\
7 \cdot 6\end{array}$ \\
\hline $\begin{array}{c}\text { Cervical } \\
\text { Spine }\end{array}$ & 258 & $5^{*}$ & $14 \cdot 6$ & 0 & $2 \cdot 6$ & 267 & 11 & $14 \cdot 7$ & 0 & $5 \cdot 0$ & $16^{*}$ & $29 \cdot 3$ & 0 & $7 \cdot 6$ \\
\hline
\end{tabular}

+ P $0.05>0.01$.

$+P 0.01>0.001$.

$\pm P<0.001$. 
had clinical rheumatoid arthritis Grade 2 to 4 and the S.C.A.T. was positive in one without other evidence of arthritis. Of the four males with Grade 3 to 4 erosions in the feet, two also had erosions in the hands; one had moderate clinical disease and a positive S.C.A.T., and the other had no clinical signs and refused a blood test. The remaining two males with Grade 3 erosions of the feet had neither clinical disease nor a positive S.C.A.T.

Of the 21 females with Grade 2 erosions in the feet, five also had erosions in the hands without clinical signs, three had clinical signs only, and none had a positive S.C.A.T.

There was no evidence that those with erosions limited to the 5th metatarsal differed from the remainder. The relationship of erosions in the feet to other evidence of R.A. is shown in Fig. 1.

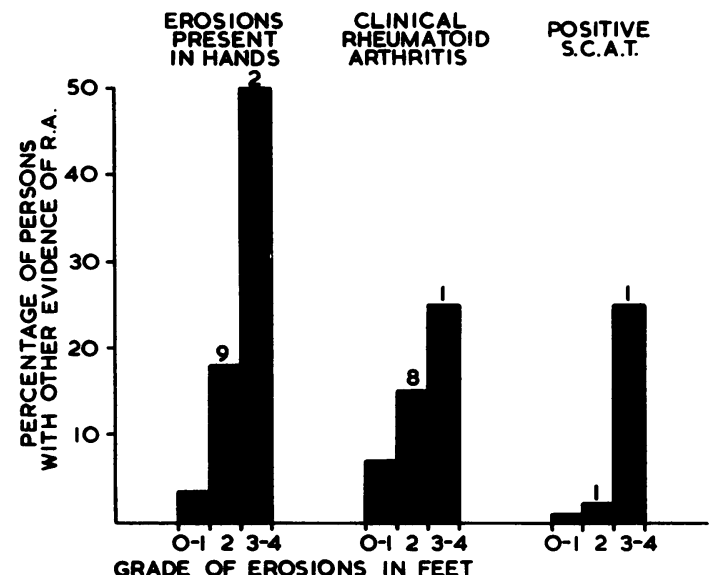

Fig. 1.-Erosions in feet related to other evidence of rheumatoid arthritis.

Erosive arthritis of the cervical spine was graded in accordance with the criteria laid down by Sharp, Purser, and Lawrence (1958). There was signifi- cantly less cervical arthritis than in Wensleydale and that which was present was mild.

Rheumatoid Serum Factors.-The S.C.A.T. was positive in six of the Jamaican males (Table V This is roughly the expected rate. In females there were fewer positive tests than expected, but the differ ence was not significant. Taking males and females together, the sheep-cell titre distribution in Jamaica and Wensleydale was almost identical (Fig. 2).

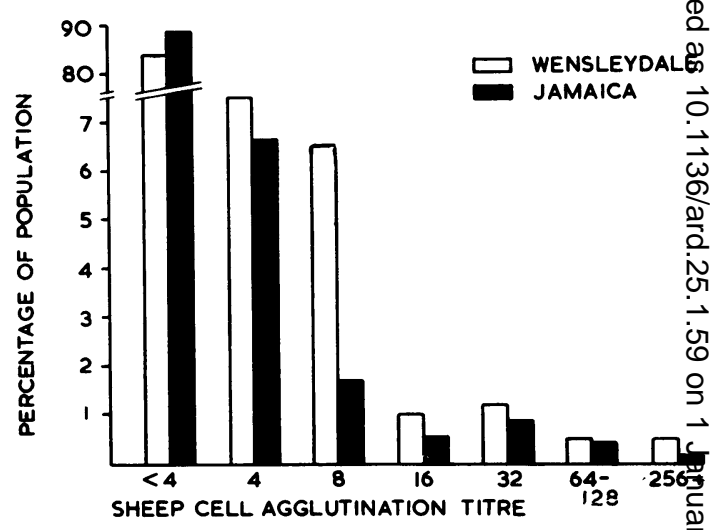

Fig. 2.-Sheep cell agglutination titres in Jamaica and Wensleydate.

The B.F.T., on the other hand, showed a laggen number of high titres in Jamaica than in Wensieydale in both sexes (Table VI and Fig. 3, opposet.

There was, however, no increase in min positive titres and the total number of positives was not significantly different.

The relationship between the serum tests alod clinical rheumatoid arthritis is shown in Table VE (opposite).

The data are taken from the 244 males and 247 females in the Jamaican survey who had both S.C.A.T. and a B.F.T. Only three of the 37 individuals with a positive S.C.A.T. or B.F.T. had arthritis. There was, in fact, almost totgl

TABLE V

S.C.A.T. RESULTS IN JAMAICA, BY AGE AND SEX

\begin{tabular}{|c|c|c|c|c|c|c|c|c|c|c|c|c|c|c|}
\hline \multirow{3}{*}{ Sex } & \multirow{3}{*}{$\begin{array}{c}\text { Age } \\
\text { Group } \\
\text { (yrs) }\end{array}$} & \multirow{3}{*}{$\begin{array}{c}\text { Total } \\
\text { Tested }\end{array}$} & \multirow{3}{*}{$<4$} & \multirow{3}{*}{4} & \multirow{3}{*}{8} & \multirow{3}{*}{16} & & \multicolumn{2}{|c|}{ S.C.A. Titre } & \multirow{3}{*}{256} & \multirow{3}{*}{512} & \multirow{3}{*}{1,024} & \multirow{2}{*}{\multicolumn{2}{|c|}{$32+$}} \\
\hline & & & & & & & \multirow{2}{*}{32} & \multirow{2}{*}{64} & \multirow{2}{*}{128} & & & & & \\
\hline & & & & & & & & & & & & & Actual & Expectent \\
\hline Male & $\begin{array}{l}35-44 \\
45-54 \\
55-64 \\
\text { Total }\end{array}$ & $\begin{array}{r}88 \\
80 \\
84 \\
252\end{array}$ & $\begin{array}{r}84 \\
70 \\
75 \\
229\end{array}$ & $\begin{array}{r}2 \\
8 \\
4 \\
14\end{array}$ & $\begin{array}{l}1 \\
2 \\
3\end{array}$ & - & $\begin{array}{l}1 \\
2 \\
3\end{array}$ & $\begin{array}{l}1 \\
1\end{array}$ & $\begin{array}{l}1 \\
1\end{array}$ & $\begin{array}{l}1 \\
1\end{array}$ & & & 6 & $3.0 \mathrm{Ns}$ \\
\hline \multirow[t]{2}{*}{ Female } & $\begin{array}{l}35-44 \\
45-54 \\
55-64\end{array}$ & $\begin{array}{l}86 \\
80 \\
87\end{array}$ & $\begin{array}{l}73 \\
72 \\
78\end{array}$ & $\begin{array}{l}9 \\
5 \\
6\end{array}$ & $\begin{array}{l}3 \\
2\end{array}$ & $\begin{array}{l}1 \\
1 \\
1\end{array}$ & 1 & 1 & & & & & & $\underline{\underline{2}}$ \\
\hline & Total & 253 & 223 & 20 & 5 & 3 & 1 & 1 & & & & & 2 & $8 \cdot 2 \mathrm{NS}$ \\
\hline
\end{tabular}

* From Wensleydale. 
TABLE VI

RESULTS OF BENTONITE FLOCCULATION TESTS IN JAMAICA, BY AGE AND SEX

\begin{tabular}{|c|c|c|c|c|c|c|c|c|c|c|c|c|c|c|c|c|}
\hline \multirow{3}{*}{ Sex } & \multirow{3}{*}{$\begin{array}{l}\text { Age } \\
\text { Group } \\
\text { (yrs) }\end{array}$} & \multicolumn{15}{|c|}{ B.F. Titres } \\
\hline & & \multirow{2}{*}{$\begin{array}{c}\text { Total } \\
\text { Tested }\end{array}$} & \multirow{2}{*}{$<4$} & \multirow{2}{*}{4} & \multirow{2}{*}{8} & \multirow{2}{*}{16} & \multirow{2}{*}{32} & \multirow{2}{*}{64} & \multirow{2}{*}{128} & \multirow{2}{*}{256} & \multirow{2}{*}{512} & \multirow{2}{*}{1,024} & \multicolumn{2}{|c|}{$>16$} & \multicolumn{2}{|c|}{$>512$} \\
\hline & & & & & & & & & & & & & Actual & Expected & Actual & Expected \\
\hline \multirow[t]{2}{*}{ Male } & $\begin{array}{l}35-44 \\
45-54 \\
55-64\end{array}$ & $\begin{array}{l}83 \\
80 \\
84\end{array}$ & $\begin{array}{l}70 \\
64 \\
66\end{array}$ & $\begin{array}{l}1 \\
1\end{array}$ & $\begin{array}{l}4 \\
5 \\
5\end{array}$ & $\begin{array}{l}2 \\
2 \\
7\end{array}$ & $\begin{array}{l}2 \\
5 \\
1\end{array}$ & $\begin{array}{l}2 \\
1 \\
1\end{array}$ & $\begin{array}{l}1 \\
1\end{array}$ & $\begin{array}{l}1 \\
1\end{array}$ & $\begin{array}{l}1 \\
2\end{array}$ & 1 & & & & \\
\hline & Total & 247 & 200 & 2 & 14 & 11 & 8 & 4 & 2 & 2 & 3 & 1 & 20 & 16 & 4 & 0 \\
\hline \multirow[t]{2}{*}{ Female } & $\begin{array}{l}35-44 \\
45-54 \\
55-64\end{array}$ & $\begin{array}{l}85 \\
81 \\
87\end{array}$ & $\begin{array}{l}63 \\
67 \\
69\end{array}$ & $\begin{array}{l}2 \\
1 \\
1\end{array}$ & $\begin{array}{l}5 \\
8 \\
5\end{array}$ & $\begin{array}{l}7 \\
2 \\
5\end{array}$ & $\begin{array}{l}2 \\
2 \\
5\end{array}$ & $\begin{array}{l}2 \\
1\end{array}$ & 2 & 1 & $\begin{array}{l}1 \\
1\end{array}$ & 1 & & & & \\
\hline & Total & 253 & 199 & 4 & 18 & 14 & 9 & 3 & 2 & 1 & 2 & 1 & 18 & 11 & 3 & 0 \\
\hline $\begin{array}{l}\text { Male+ } \\
\text { Female }\end{array}$ & & 500 & 399 & 6 & 32 & 25 & 17 & 7 & 4 & 3 & 5 & 2 & $38 \mathrm{NS}$ & 27 & 78 & 0 \\
\hline
\end{tabular}

NS $=$ Not significant

$\mathbf{S}=$ Significant

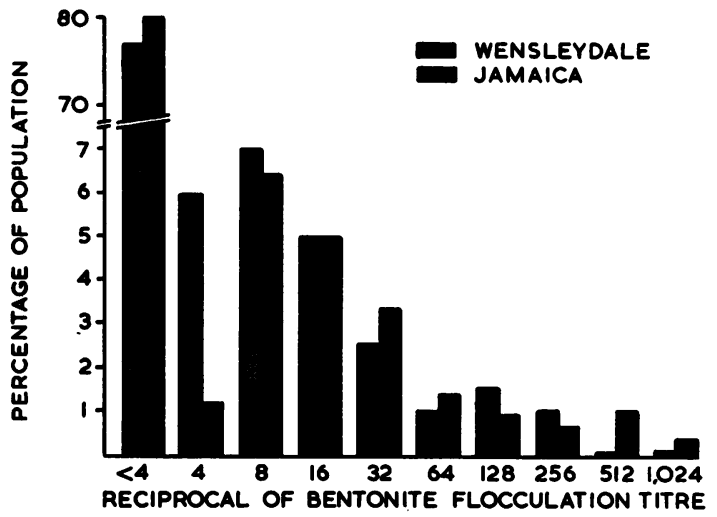

Fig. 3.-Bentonite flocculation titres in Jamaica and Wensleydale.

discord between the serology and the clinical state. Of those in whom both tests were negative, 35 (8 per cent.) had rheumatoid arthritis; of eight with a positive S.C.A.T. one (12 per cent.) had rheumatoid arthritis, compared with three (8 per cent.) of the 36 with a positive B.F.T., and one ( 20 per cent.) of the five in whom both tests were positive (Fig. 4). In view of the small numbers with positive tests, the association cannot be considered significant.

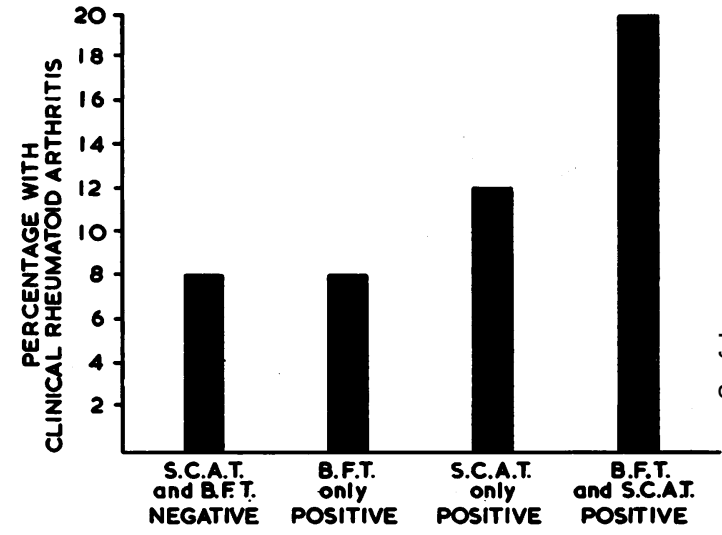

Fig. 4.-Serological tests and presence of clinical rheumatoid arthritis.

The relationship of clinical to radiological evidence of R.A. is shown in Table VIII (overleaf). Of the six with Grade 3 clinical R.A., three had radiological evidence of the disease and two had a positive serological test. Of the 34 with Grade 2 clinical R.A., nine had radiological evidence but only one had a positive serum test. Thus only three of the forty clinical cases of R.A. were sero-positive

TABLE VII

RELATIONSHIP OF S.C.A.T. AND B.F.T. TO GRADE OF CLINICAL R.A. IN JAMAICA

\begin{tabular}{|c|c|c|c|c|c|c|c|c|c|c|c|c|}
\hline \multirow{2}{*}{ 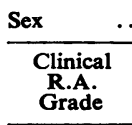 } & \multicolumn{6}{|c|}{ Male } & \multicolumn{6}{|c|}{ Female } \\
\hline & $\begin{array}{l}\text { S.C.A.T. } \\
\text { and B.F.T. } \\
\text { Negative }\end{array}$ & $\begin{array}{l}\text { S.C.A.T. } \\
\text { Only } \\
\text { Positive }\end{array}$ & $\begin{array}{c}\text { B.F.T. } \\
\text { Only } \\
\text { Positive }\end{array}$ & $\begin{array}{l}\text { S.C.A.T. } \\
\text { and B.F.T. } \\
\text { Positive }\end{array}$ & Total & $\begin{array}{l}\text { Incom- } \\
\text { plete }\end{array}$ & $\begin{array}{l}\text { S.C.A.T. } \\
\text { and B.F.T. } \\
\text { Negative }\end{array}$ & $\begin{array}{c}\text { S.C.A.T. } \\
\text { Only } \\
\text { Positive }\end{array}$ & $\begin{array}{c}\text { B.F.T. } \\
\text { Oniy } \\
\text { Positive }\end{array}$ & $\begin{array}{l}\text { S.C.A.T. } \\
\text { and B.F.T. } \\
\text { Positive }\end{array}$ & Total & $\begin{array}{c}\text { Incom- } \\
\text { plete }\end{array}$ \\
\hline Total & 222 & 2 & 16 & 4 & 244 & 19 & 230 & 1 & 15 & 1 & 247 & 25 \\
\hline $\begin{array}{l}3 \\
2 \\
1 \\
0\end{array}$ & $\begin{array}{r}1 \\
10 \\
18 \\
193\end{array}$ & $\bar{z}$ & $\begin{array}{r}-1 \\
1 \\
14\end{array}$ & $\frac{1}{3}$ & $\begin{array}{r}2 \\
11 \\
19 \\
212\end{array}$ & 二 & $\begin{array}{r}2 \\
22 \\
14 \\
192\end{array}$ & $\bar{z}$ & $\frac{1}{31}$ & $\bar{z}$ & $\begin{array}{r}3 \\
22 \\
17 \\
205\end{array}$ & 二 \\
\hline
\end{tabular}


TABLE VIII

RELATIONSHIP OF CLINICAL AND RADIOLOGICAL EVIDENCE OF R.A. IN JAMAICA TO POSITIVE S.C.A.T. OR B.F.T.

\begin{tabular}{l|c|c|c|c}
\hline & \multicolumn{2}{|c|}{ Grade of Clinical or Radiological R.A. } \\
\cline { 2 - 4 } Evidence of R.A. & Total & $\begin{array}{c}\text { Positive S.C.A.T. } \\
\text { or B.F.T. }\end{array}$ & Total & $\begin{array}{c}\text { Positive S.C.A.T. } \\
\text { or B.F.T. }\end{array}$ \\
\cline { 2 - 4 } & 25 & 1 & 3 & 1 \\
\hline $\begin{array}{c}\text { Clinical Only } \\
\text { Radiological } \\
\begin{array}{c}\text { Only } \\
\text { Clinical and } \\
\text { Radiological }\end{array}\end{array}$ & 9 & 5 & 3 & 0 \\
\hline
\end{tabular}

compared with seven of 53 clinical cases in Wensleydale. Clinically, the R.A. cases in Jamaica and Wensleydale were very similar. There was commonly pain and swelling or limitation of the PIP and MCP joints, limitation of one or both wrists and the cervical spine, and limitation with or without subluxation of the lateral MTP joints. Knee effusions were more frequent in the Jamaicans and in general complaints of symptoms in the joints of the lower limbs were more numerous.

Of those with only radiological evidence of R.A., three had Grade 3 changes. None of these had a positive serum test. Two had a large erosion on the head of one 5th metatarsal with no history of injury, and the third had an irregularity of the 1st cuneiform, with small erosions elsewhere, a blood sample being refused.

Urinary Infection and Rheumatoid Arthritis.None of the males had any evidence of urinary infection, but ten females had a positive result on mid-stream specimens of urine. Nine of these were examined by a rheumatologist, but none had clinical evidence of rheumatoid arthritis. Of eight tested by the S.C.A.T., none was positive but of ten tested by the B.F.T., two were positive, one having a titre of 1:512. In view of the small numbers, no conclusions can be drawn from these findings, but the distribution of B.F. titres is of some interest in view of the results of animal inoculations with $E$. coli, and this aspect is being further studied in the population of Wensleydale.

Sinusitis.-Radiological evidence of sinusitis (mucosal thickening, general opacity, or a fluid level) was present in 63 males and 102 females in the Jamaican sample. There was no significant difference between those with and without sinusitis as regards clinical, radiological, or serological evidence of rheumatoid arthritis. Only the B.F.T. was more often positive in those with sinusitis (Fig. 5) and this increase was limited to females and was not significant.

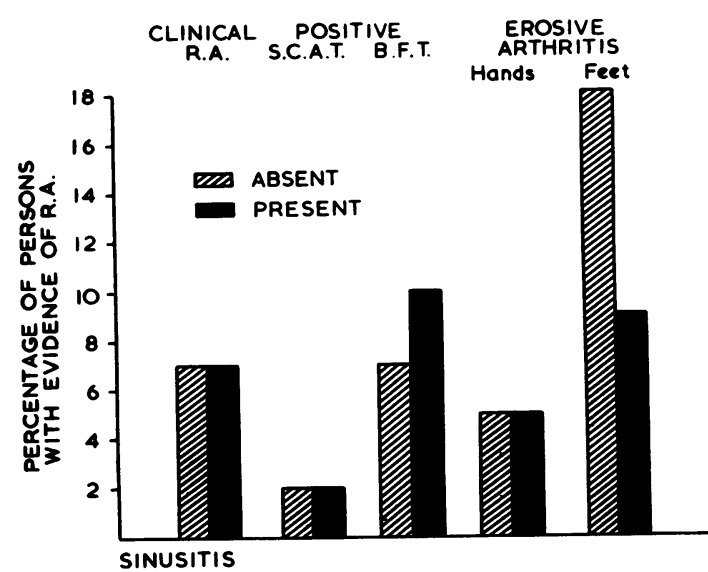

Fig. 5.-Rheumatoid arthritis in persons with sinusitis.

Hospital Patients.-In addition to the population $-\vec{c}$ sample, a series of arthritic hospital patients from the registers of the University College Hospital, Kingston, was examined. There were 78 of whom only 41 could be contacted (Table IX); a diagnosis of rheumatoid@ arthritis was made in 23 (eleven severe and ten? moderate). There were six cases of Stills' disease, of whom four had severe changes. Three patientswith polyarthritis had made a complete recovery agd\%

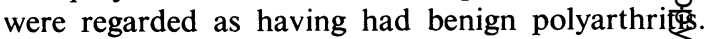
There were two cases each of spondylitis, Reites 50 disease, and osteo-arthrosis, and one each rheumatic fever and systemic lupus erythematosus.o One had an ankylosed hip which was thought toô have been tuberculous. Thus it is clear that rheumatoid arthritis accounts for an appreciable $\overrightarrow{0}$ proportion of arthritic patients admitted to hospitaB in Jamaica and that some of them are severe. At? least two of these patients had been bed-ridden? for a number of years. The proportion with Still'so disease was high, but this may simply reflect the age-distribution of the population.

TABLE IX

DIAGNOSTIC GROUPING OF 41 ARTHRITIC HOSPITAL PATIENTS SEEN IN JAMAICA

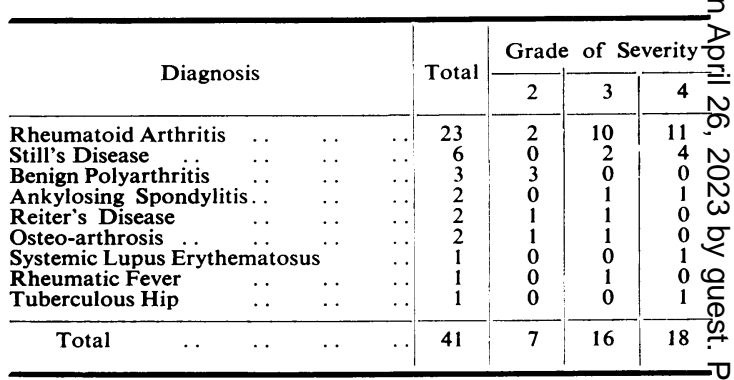


A perusal of the notes of 37 patients who were not examined showed a similar distribution of diagnoses.

\section{Discussion}

From the results of this survey it is clear that rheumatoid arthritis does occur in persons of Negroid stock living in the subtropical zone. It is moreover clear that it occurs at least as frequently as in a Caucasian population in the U.K. The apparently low prevalence of severe disease and the relatively high proportion of individuals with minimal disease is of interest. It would seem that the Jamaican population has a relatively high predisposition to rheumatoid arthritis but that they tend to have a milder form of the disease. The discrepancy between clinical disease and serology is also interesting. It should be pointed out however, that minimal disease generally bears little relationship to serology in population samples and that it is in the more severe cases that concordance between clinical, X-ray and serological findings is normally encountered. Family studies might elucidate this kind of problem but because of the loose family structure in the Jamaican population this is impracticable.

The high titres found with the bentonite test in Jamaica do not seem to be related to arthritis except when the sheep-cell test is also positive. This would confirm the findings of Williams and Kunkel (1963) that it is mainly the rheumatoid factor reacting with both rabbit and altered human $\gamma$ globulin which is associated with rheumatoid arthritis.

It would seem unlikely that the low sheep-cell titre in females and the high bentonite titres in both sexes in the Jamaican population are racial. Waller, Toone and Vaughan (1964) found no significant difference between "normal" Negroes and Whites in Richmond, Virginia, as regards the frequency of positive tests by the sheep cell and latex methods. Technical reasons for the JamaicaWensleydale differences can be ruled out in the case of the S.C.A.T. since the sera in both surveys were tested in the same laboratory, using the same standard controls. Nor would technical causes seem likely in the case of the B.F.T. since it is only the high titres which were increased, the minimal positive titres being unaffected.

The high prevalence of single localized erosions in the metatarso-phalangeal joints raises the question whether trauma may be responsible, either as a cause of non-rheumatoid erosions or as determining which joints shall be involved in the rheumatoid process. The association between these erosions and other evidence of rheumatoid arthritis would make the latter the more probable explanation if trauma is involved but it is quite possible that a proportion of the erosions are purely traumatic. The occurrence of traumatic erosions has been demonstrated by Crock (1964).

\section{Summary}

A population sample aged $35-64$, having 100 males and 100 females in each decade, living in a rural area in Jamaica has been submitted to a clinical examination of the musculo-skeletal system and to routine $x$ rays of the hands, feet, knees, cervical and lumbar spine, pelvis and sinuses. A blood sample was taken for the sheep-cell and bentonite flocculation tests and a mid-stream sample of urine for bacteriological examination. Comparison was made with a similar population sample living in Wensleydale, England. The completion rate in the Jamaican sample was 88 per cent. in males and 91 per cent. in females.

There was no significant difference in the prevalence of rheumatoid arthritis as graded by the Rome criteria but probable disease tended to be increased and definite disease diminished. A clinical diagnosis of rheumatoid arthritis as made by the physician at the time of examination also showed no significant difference between the Jamaican and Wensleydale populations except in the 55-64 age group in males. Minimal disease tended to be increased in both sexes but no severe cases were encountered.

There was significantly more erosive arthritis in the hands and feet as determined radiologically in the Jamaican population. The most striking differences were found in the feet but the changes were for the most part minimal and limited to one or other of the 5th metatarso-phalangeal joints. Moderate or severe erosions were not more frequent in Jamaica than in Wensleydale. Rheumatoid arthritis of the cervical spine was less frequent in the Jamaican than in the Wensleydale population.

The sheep-cell agglutination test was positive in the same proportion of Jamaican and Wensleydale males but the Jamaican females had fewer positive tests. High titres by the bentonite flocculation test were more frequent in both sexes in Jamaica.

There was no definite relationship between either sinusitis or urinary infection and rheumatoid arthritis or rheumatoid serum factors.

We are indebted to Dr. W. E. Miall for allowing us to take part in his survey, to Professor E. H. Kass of Boston for permission to use his bacteriological results and to Dr. R. Hinchcliffe and his colleagues of the Institute of Laryngology and Otology of the University of London 
for their $x$-ray readings on the sinus films. Above all we are grateful to the inhabitants of the Lawrence Tavern area of Jamaica for their generous co-operation in this study.

\section{REFERENCES}

Cobb, S., and Lawrence, J. S. (1957). Bull. rheum. Dis., 7, 133.

C.I.O.M.S. criteria (1963). In "The Epidemiology of Chronic Rheumatism", ed. J. H. Kellgren, p. 324. Blackwell, Oxford.

Crock, H. V. (1964). J. Bone Jt Surg., 46B, 530.

Gelfand, M. (1957). "The Sick African", 3rd ed. Juta, Capetown.

Goodall, J. W. D. (1956). Centr. Afr. J. Med., 2, 220.

de Graaff, R., Laine, V., and Lawrence, J. S. (1963). In "The Epidemiology of Chronic Rheumatism", ed. J. H. Kellgren, p. 228. Blackwell, Oxford.

Harries, J. R. (1962). E. Afr. med. J., 39, 69.

Hijmans, W., Valkenburg, H. A., Muller, A. S., and Gratama, S. (1964). Ann. rheum. Dis., 23, 45.

Malawista, S. E., Boies, L. R., Jr., and Seides, S. W. (1959). Ibid., 18, 305.

Méndez-Bryan, Gónzalez-Alcover, R., and Roger, L. (1964). Arthr. and Rheum., 7, 171.

Sharp, J., Purser, D. W., and Lawrence, J. S. (1958). Ann. rheum. Dis., 17, 303.

Waller, M., Toone, E. C., and Vaughan, E. (1964). Arthr. and Rheum., 7, 513.

Williams, R. C., and Kunkel, H. G. (1963). Ibid., 6, 665.

\section{Arthrite rhumatismale dans une population sous-tropicale}

\section{RÉSUMÉ}

Un échantillon de la population d'une région rurale de la Jamaïque, comprenant 100 hommes et 100 femmes par chaque dizaine d'années entre les âges de 35 à 64 ans, fut soumis à l'examen clinique du système musculosquélettique et aux radiographies systématiques des mains, des pieds, des genoux, de la colonne cervicale et lombaire, du bassin et des sinus. On fit des prélèvements du sang pour les réactions de Waaler-Rose et de floculation à la bentonite et on procéda à l'examen bactériologique du deuxième jet d'urine. Les résultats furent comparés avec ceux obtenus dans un échantillon similaire de la population de Wensleydale, Angleterre. Parmi les Jamaicains l'enquête fut totalement accomplie en 88 pour cent des hommes et en 91 pour cent des femmes.

On n'observa pas de différence significative dans la fréquence de l'arthrite rhumatismale, diagnostiquée selon les critères de Rome, mais la maladie "probable" tendait à augmenter et la "certaine" à diminuer. Le diagnostic de l'arthrite rhumatismale fait par le clinicien au moment de l'examen fut peu différent dans les populations de la Jamaïque et de Wensleydale, sauf pour les hommes âgés de 55 à 64 ans. La maladie "minime" tendait à augmenter parmi les personnes des deux sexes, mais on ne trouva pas de cas graves.

Il y eut significativement plus d'arthrite érosive des mains et des pieds, déterminée radiologiquement, parmi les Jamaïcains. On trouva les différences les plus frappantes dans les pieds, mais les altérations furent dan la plupart des cas minimes et se limitaient à une des deux articulations métatarso-phalangiennes du 5-ème ortei Des érosions "modérées" ou "sévères" ne furent pas pluł fréquentes à la Jamaïque qu'à Wensleydale. L'arthrité rhumatismale cervicale fut moins fréquente dans $1 \overline{\bar{S}}$ population jamaïcaine que dans celle de Wensleydale.

La réaction de Waaler-Rose fut positive dans la mêmę proportion des hommes de la Jamaïque que de Wensley dale, mais les femmes jamaïcaines accusèrent moins do réactions positives. Des titres élevés de la réaction dô floculation à la bentonite furent plus fréquents parmi les personnes des deux sexes à la Jamaïque.

On ne trouva pas de rapport défini entre la sinusite ou. l'infection urinaire d'une part et l'arthrite rhumatismale ou les facteurs sériques rhumatismaux de l'autre.

Artritis reumatoide en una población subtropical

\section{Sumario}

Una muestra de la población de una región rural do Jamaica, comprendiendo 100 hombres y 100 mujeres en cada decenio entre las edades de 35 y 64 años, fứ sometida al examen clínico del sistema músculó esquelético y a radiografías sistemáticas de manos, pie rodillas, de la columna cervical y lumbar, de la cadera de los senos. Se recogió sangre para las reacciones de Waaler-Rose y de floculaciòn de bentonita y se analiz'́ bacteriològicamente el corriente medio de la orina. compararon los resultados con los obtenidos en ina muestra similar de la población de Wensleydalę Inglaterra. Se pudo completar la investigación jamaicanis en un 88 por ciento de los hombres y un 91 por ciento de las mujeres.

No se observó diferencia significativa en la frecuenci⿱⿱宀八九丸 de la artritis reumatoide, diagnosticada según los criterios de Roma, pero la enfermedad "probable" tendía a aumentar y la "cierta" a disminuir. El diagnóstic 8 clínico de la artritis reumatoide hecho por el médico all tiempo del examen reveló poca diferencia entre ląs poblaciones de Jamaica y de Wensleydale, con Ia excepción de los hombres en el grupo de edades entrę 55 y 64 años. La enfermedad "mínima" tendía $\frac{\mathscr{E}}{\sqrt{3}}$ aumentar en ambos sexos, pero no se encontraron casos graves.

Se vieron significativamente más casos de artritǔs erosiva de las manos $y$ de los pies, determinad@ radiográficamente, entre los jamaicanos. Las má notables diferencias fueron encontradas en los pies, pero las alteraciones fueron en su mayor parte mínimas y se limitaron a una de las dos articulaciones metatarso falángeas del quinto. Erosiones "moderadas" o "severas no fueron más frecuentes en Jamaica que a Wensleydale La artritis reumatoide cervical fué menos frecuente en læ población jamaicana que en la de Wensleydale.

La reacción de Waaler-Rose fué positiva en la mism\$ proporción de los jamaicanos que de los hombres de Wensleydale, pero las jamaicanas acusaron menos reacciones positivas. Cifras elevadas de la reacción dê floculación de bentonita fueron más frecuentes en ambơ sexos en Jamaica.

No hubo relación apreciable entre la sinusitis o le infectión urinaria por un lado y la artritis reumatoide oo los factores séricos reumatoides por el otro. 